\title{
The European regulatory state at risk? : The EU as a regulator of complex policy problems
}

Citation for published version (APA):

Versluis, E. (2016). The European regulatory state at risk? : The EU as a regulator of complex policy problems. Maastricht University. https://doi.org/10.26481/spe.20160219ev

Document status and date:

Published: 19/02/2016

DOI:

10.26481/spe.20160219ev

Document Version:

Publisher's PDF, also known as Version of record

\section{Please check the document version of this publication:}

- A submitted manuscript is the version of the article upon submission and before peer-review. There can be important differences between the submitted version and the official published version of record.

People interested in the research are advised to contact the author for the final version of the publication, or visit the DOI to the publisher's website.

- The final author version and the galley proof are versions of the publication after peer review.

- The final published version features the final layout of the paper including the volume, issue and page numbers.

Link to publication

\footnotetext{
General rights rights.

- You may freely distribute the URL identifying the publication in the public portal. please follow below link for the End User Agreement:

www.umlib.nl/taverne-license

Take down policy

If you believe that this document breaches copyright please contact us at:

repository@maastrichtuniversity.nl

providing details and we will investigate your claim.
}

Copyright and moral rights for the publications made accessible in the public portal are retained by the authors and/or other copyright owners and it is a condition of accessing publications that users recognise and abide by the legal requirements associated with these

- Users may download and print one copy of any publication from the public portal for the purpose of private study or research.

- You may not further distribute the material or use it for any profit-making activity or commercial gain

If the publication is distributed under the terms of Article $25 \mathrm{fa}$ of the Dutch Copyright Act, indicated by the "Taverne" license above, 


\section{Maastricht University}

\section{Inaugurele rede}

Prof. dr. Esther Versluis

Faculteit der Cultuur- en Maatschappijwetenschappen

\section{The European regulatory state at risk? : \\ The EU as a regulator of complex policy problems}




\section{Maastricht University}

Faculty of Arts and Social Sciences

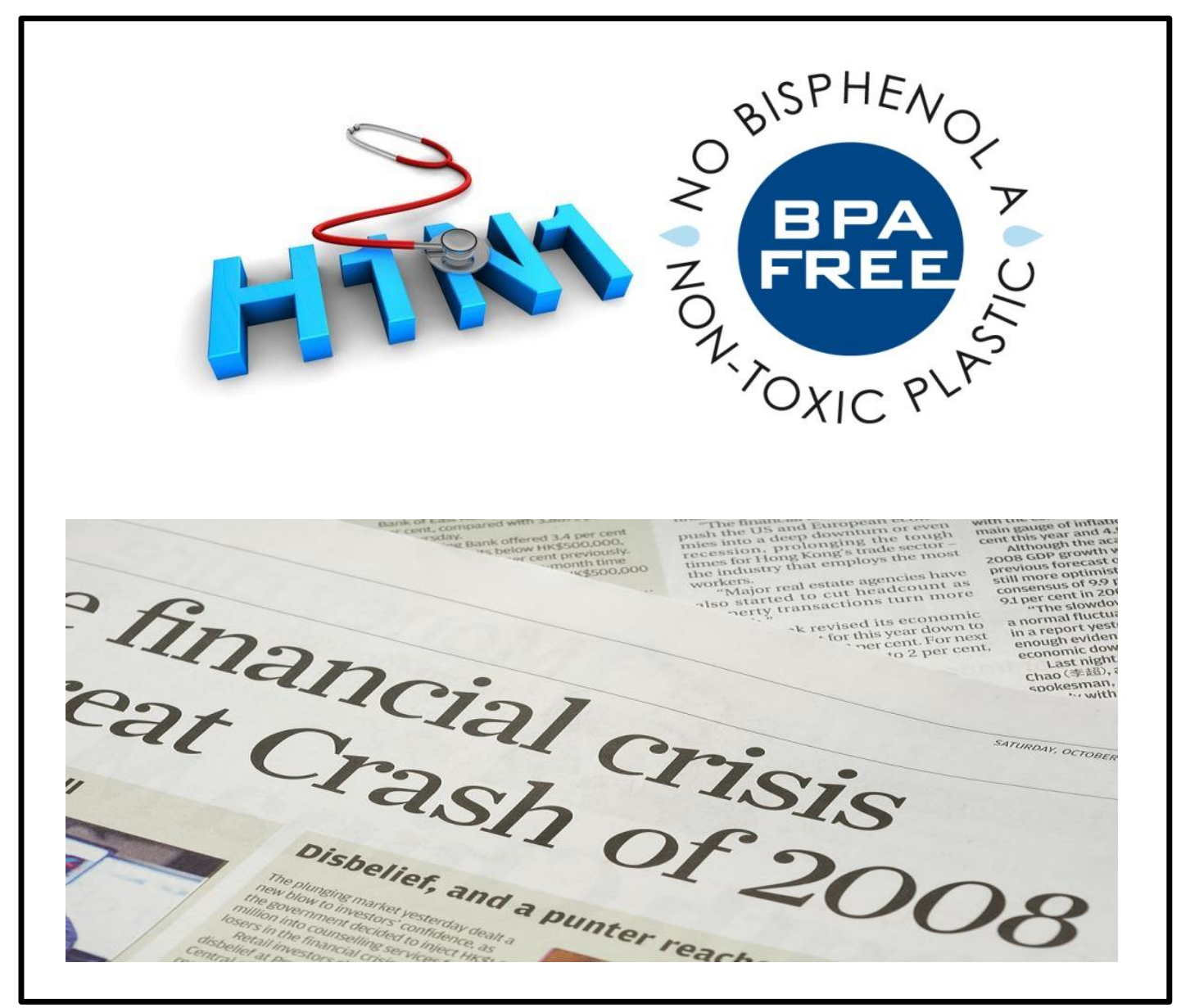

INAUGURAL LECTURE - PROF.DR. ESTHER VERSLUIS

Chair European Regulatory Governance

19 February 2016 


\section{THE EUROPEAN REGULATORY STATE AT RISK? THE EU AS A REGULATOR OF COMPLEX POLICY PROBLEMS}

Sometimes the European Union (EU) decides about the color and the curves of bananas, sometimes the EU has to decide about the handling of large streams of refugees. Some policy problems simply are more complex than others. With the acceptance of this chair in European Regulatory Governance, I intend to spend the upcoming years analyzing the European Union as a regulator of complex policy problems.

In recent years, we have witnessed problems in very diverse policy fields and at all kinds of levels: think of the mad cow disease (BSE), genetically modified maize (GMOs), swine flu (H1N1), volcanic ash, the Eurozone crisis, Ebola, the refugee crisis and international terrorism. Such problems are increasingly transboundary as modern societies are more and more interconnected, and geographical borders and policy boundaries become less and less relevant. There is no such thing as a Dutch environmental problem. Problems related to the environment in the Netherlands are transboundary in the sense that they are interconnected with related problems in other neighboring European countries. And they are interconnected with problems related to other policy sectors such as the economy - think of ever growing consumption patterns -, or trade - think of the impact of creasing global trade on the environment. As a result, risks and uncertainties easily spread over very diverse policy and country borders.

Such transboundary policy problems are hard to manage due to the fragmentation of authority; who owns, and is thus responsible for such transboundary policy problems? Particularly in the European Union, no single actor, public or private, could solve complex policy problems alone. This stems from the fact that the EU is an international organization in which we witness a diversity in political cultures and regulatory frameworks. Put more generally, in the multi-level context of the EU - where different Member States are affected by different circumstances and where different political, social and economic systems are brought together - regulation is often complex and challenging.

Let's take the ongoing refugee problem as an example. This problem by definition is transboundary, crossing both national and sectoral borders. To start with the sectoral borders, from an economic perspective, the refugee crisis is mainly a cost-benefit problem: what is the economic impact of increasing or decreasing immigration numbers on the national and European economy? Cultural scientists will stress the impact of religious and cultural fault-lines on the attitude and behavior of both immigrants as well as the European civil society on potential integration problems. From an international relations perspective, the problem lies more in the disturbed balance of power between different regions in the world, and the nature of the conflict in Syria impacting on immigration flows and terrorist activity. In sum, different sectoral or disciplinary perspectives highlight different parts of the wider problem. The same can be said for different country perspectives. Nobody will counter the argument that the refugee 
problem does not play out the same in Greece and Hungary, as in Scandinavia. And thus the way the refugee crisis is defined and how this needs to be solved, will be different for these different types of countries. Yet at the same time it is obvious that no country can solve this problem alone, and that European action is needed.

The core question that the existence of such complex policy problems brings along is the question how to handle such problems. In the years to come I intend to concentrate on precisely this: How does the EU regulate complex policy problems?

\section{Framing the regulation of complex policy problems}

Why do I concentrate on the regulation of complex policy problems? The EU is a regulatory state (Majone, 1997); its core approach to policy problems is regulation. But what is regulation? For right-wing parties regulation is a dirty word representing the hand of authoritarian governments, while for left wing democrats it can refer to a tool to control eager capitalists. For legal scholars it refers to legal instruments, while for sociologists it can also include forms of social control (Levi-Faur, 2010). To make it even more complex, in the European Union, one of the binding legal instruments is a 'regulation'. This is not what I refer to when I talk about regulation. I follow the broader definition of regulation, referring to everything governments do to establish, monitor and control norms (following Scott, 2001).

My aim is to provide a better understanding of how the EU handles complex policy problems via regulation. And here we come to the core: what are complex policy problems and how can we analyze them? In the most general understanding of the term, a policy problem is a 'condition that some or all citizens (and policymakers) find undesirable' (Peters, 2015: 13). Some policy problems may be considered simple, others more complex. What is complexity then in this context? There is no single answer to this question, as different disciplines research the same topic yet use different terminology. Public policy scholars talk about 'wicked problems', political scientists discuss the regulation of 'crises', and science and technology studies colleagues are more concerned about 'risks'. In the end, while discussing this issue using a variation of concepts, in principle these different school address the same topic: how do we deal with complex policy problems? Let's briefly discuss what main lessons we can learn from these different disciplinary traditions in their analysis of this topic.

\section{Complex policy problems as wicked problems}

The early 1970s showed an increasing dissatisfaction with rational-technical approaches to decision-making. This dissatisfaction stemmed from the increasing belief that the traditional way of thinking about organizational decision-making - there is a problem, we define the possible decision alternatives, we examine their potential consequences, and we finally decide - does not very much capture reality. Rittel and Webber (1973) are considered to be the founding fathers of the 'wicked problem'. According to this line of thinking there are simple problems and wicked problems. 
Simple, or tame, problems are those where problem definition and solution to the problem are understood. Tame problems are easy to define, information needed to solve the problem is available, and there is consensus on both the problem and the solution. For example the regulation of the color and the curves of bananas that I mentioned earlier is a simple problem. Wicked problems are those where both nature of the problem and solution are uncertain and controversial (Durant and Legge, 2006: 329). As Rittel and Webber put it: 'The formulation of a wicked problem is the problem!' (1973: 161; emphasis in original). Wicked problems are not objectively defined, nor are there objectively valid solutions; this is in the eye of the beholder (Coyne, 2005). There will always be variation in judgment about wicked problems according to personal interests, and ideological viewpoints (Rittel and Webber, 1973). Wicked problems can never be definitely solved; solutions are not true-or-false, but good-or-bad. Take the refugee crisis as an example: it is crystal clear that the problem can never be objectively defined, nor are there any objectively valid solutions. This is indeed in the eye of the beholder.

\section{Complex policy problems as risk problems}

A second stream in the literature discusses the regulation of complex policy problems by referring to risks. We live in a risk society where growing uncertainties have to be accepted because they can only be managed and never be completely eliminated (Beck, 1986). The core reason for this is that these risks are unforeseen side effects of the industrialized modernity, while science does not provide us with the necessary knowledge to manage them in the current policy framework (Taylor-Gooby and Zinn, 2006). Increasing globalization, as well as increasing complexity of our technologies, influence the levels of complexity and uncertainty, making the reliance on and acceptance of probabilistic calculations increasingly impossible (Taylor-Gooby and Zinn, 2006). Necessary information on probability and extent of damage is often not available, in turn affecting the role of (and trust in) experts and scientific advice. The higher the levels of ambiguity and uncertainty, the more difficult it becomes for policy-makers to define their preferences, and the more dependent they become on experts and scientific advice. But all such advice is embedded in prior, socially derived framing assumptions (Jasanoff and Wynne, 1998), so we need to realize that there is no knowledge without interests (Radaelli, 1999).

We can thus say that 'risks are mental constructions. They are not real phenomena but originate in the human mind' (Renn, 2008: 20; quoted in Mansnerus, 2010: 8). Thus risk perceptions amongst individuals vary. Whether people are risk averse or risk taking is influenced by the amount of knowledge about the risk at hand, the personality, the economic situation, the political position, and particularly the cultural background or worldview (Wildavsky and Drake, 1990). It is thus not surprising that how societies handle risks very much relates to institutional, procedural, social and cultural dimensions. The way in which a country regulates risks is linked to prevailing risk perceptions and levels of uncertainty intolerance (Van Asselt and Vos, 2008). Regulating risks is complex, particularly in contexts such as the EU where there is diversity in 
political cultures, regulatory frameworks, and standards in risk assessment. Linking this to the example of the refugee crisis, we clearly see that the risks of increasing refugee numbers are differently defined by Turkey than by Sweden.

\section{Complex policy problems as crisis problems}

Let's turn from risks to crises. In defining crises I follow Boin et al. (2009: 83-4) who describe crises as 'events or developments widely perceived by members of relevant communities to constitute urgent threats to core community values and structures'. A crisis might lead to a situation in which core values and structures dominant in a particular policy community are threatened or disrupted, and thus that the normal way of doing things stops making sense (Alink et al., 2001). While we have discussed the difference between tame and wicked problems before, the crisis literature comes to a similar type of categorization yet labelled differently: here we speak of well-structured versus ill-structured problems, with crises labelled as ill-structured problems or messes (Mitroff et al., 2004).

Just as wicked problems and risks are subjectively defined phenomena, the same applies to crises. A crisis is never objectively given, and part of it is always socially constructed. It can be in the interest of certain actors to label something as a crisis, particularly as crises are labelled as willful action or stem from human malfeasance in Birkland's definition of the concept (Birkland, 2006: 4). Also solutions or problems are no objectively given concepts, but are 'constantly changing as they are embedded in cognitive and organizational parameters' (Borrás and Radaelli, 2011: 469). Analyzing crises implies that we analyze the framing, the language used. Boin et al. (2009: 81) summarize this clearly, when stating that '[c]rises thus generate framing contests to interpret events, their causes, and the responsibilities and lessons involved in ways that suit their political purposes and visions of future policy directions' (emphasis added).

An important component of the crisis literature is its focus on crisis or disaster management. How do organizations cope with and manage crises? The literature brings forward a wide body of mostly empirical case studies that track government behavior in all sorts of fields, ranging from the US government's approach to 9/11 or the hurricane Katrina, to the EU's response to BSE or Iraq. What we learn from these case studies is the problematic fragmentation of authority and thus a lack of clear ownership: who feels responsible - feels to have a sufficient legitimacy base - for tackling the crisis at hand? Crises lead to 'politics of urgency' where it is easier to push for certain decisions, as the sense of urgency leads to more readiness for change (Wexler, 2009). Just as the wicked problem literature teaches us that such problems cannot be solved, and the risk literature informs us that many risks are uncertain and unknown, the crisis literature discusses that crisis prevention is essentially impossible (Boin, 2004). Rather than trying to prevent crises, organizations should become resilient and learn to cope with unanticipated dangers and learn to bounce back (Wildavsky, 1988). 
Towards an interdisciplinary understanding of complex policy problems: subjectivity, framing and perceptions

What do we now learn from this wide body of literature on wicked problems, risks and crises? Whatever approach one puts center-stage, one thing becomes very clear from the different approaches: There is no such thing as an objectively identified policy problem. This is in the eye of the beholder, and is embedded in social, cultural, normative, and administrative contexts. And thus framing is of crucial importance; how stakeholders involved in the game frame the problem and the potential solutions is key. Every perspective about the nature of a problem implies a preferred solution. Thus, those in control of framing the policy problems determine the types of potential solutions that are perceived as most reliable, or to put more bluntly, defining the policy problem is an exercise in power. Slovic (1999: 689) summarizes this very nicely, when he states that decision-making about complex policy problems, but also in general, is inherently subjective and represents a blending of science and judgment with important psychological, social, cultural, and political factors.'

Particularly in the EU, the definition, perception, and foreseen impact of any given policy problem will never be exactly the same for all 28 member states. Let's return to the example of the refugee problem. How this complex policy problem is framed in the different parts of the European Union is completely different. The definition of the problem in Greece is a different one compared to how the problem is defined in the United Kingdom. It is not possible to provide an objective description of the refugee problem. In fact, the term refugee itself is contested by alternatives like economic migrants (and other, less scientific ones). Nor is there a clear and simply identifiable solution readily available, partly because the relevant evidence needed to understand the problem can never be complete. We have no way of knowing exactly what the impact of continuous streams of refugees is on societal and economic situations in different member states. Nor will we ever have full understanding of the precise nature of the problems in Syria. A further complicating factor is that the problem also constantly changes. With every new event happening, think of the problematic situation in Cologne on New Year's eve, the problem, and thus its potential solution, changes.

How does the fact that complex policy problems cannot be objectively defined, solutions cannot be provided, evidence can never be complete, and thus they can never be solved, impact the capability of the European Union to deal with such complex policy problems? How can the EU - with its ever limited resources and a contested legitimacy base regulate a situation in which there is no consensus on the problem at hand, nor on the potential solutions, and of which we know upfront that the problem can actually never be solved? 


\section{Expertise and scientific advice in the system of EU regulatory governance}

Insights into how political institutions deal with disasters such as Chernobyl in the mid1980s, the BSE crisis in the early 1990s, the social policy crisis in the beginning of the century (Hoenderkamp, 1998), and more recently the financial crisis - to name just a few examples - illustrate the potential weaknesses of regulating complexity. Before I move on to outlining how the EU deals with complex policy problems, it is good to stress that dealing with complexity is by no means something new or restricted to the European Union. An overview article by Schillemans (2013) illustrates how scholars in the late 1800 s already addressed this theme, nicely captured in the words of Wilson who in 1887 stated that 'the functions of government are every day becoming more complex and difficult' (Wilson, 1887, pp.200-201; quoted in Schillemans, 2013, pp.75-76).

\section{European agencies as a response to complexity}

The current response to this growing complexity shows an increasing reliance on European-level agencies. The EU more and more tends to resort to the build-up of regulatory capacity via committees, expert groups, agencies and networks, and as such to the institutionalization of what has become known as the EU's regulatory space. Agencies are a popular form of regulatory governance since the 1990s. And not only in the EU. 'Agencification' is a common trend in most advanced industrial democracies (Braun and Gilardi, 2006). This strategy is rooted in the 'belief' that agencies through (independent) expertise and apolitical, high quality evaluations will lead to better decisions, more efficiency and increased accountability (e.g. Gilardi, 2002). Agencies such as the European Chemicals Agency (ECHA), the European Food Safety Authority (EFSA), and the European Medicines Agency (EMEA) have an explicit role in risk assessment. These agencies have, for example, an important, if not decisive, role in evaluating whether particular products can be produced, imported and sold in the EU. This illustrates that independent regulatory agencies are expected to provide better (technical) expertise and are capable of making more credible policy decisions. Faith in expertise has always been an important justification for the delegation of power to regulators such as agencies (Majone, 1997). And here we come to the role of knowledge and expertise in the regulation of complex policy problems.

\section{The role of knowledge and expertise in regulating complex policy problems}

'Who decides what knowledge is, and who knows what needs to be decided?' (Lyotard, 1986: 9).

The increasing reliance on agencies and other types of networks and expert-groups indicates a reliance on evidence-based policy-making. Becoming a popular notion in the late 1990s, particularly advocated by the first Blair government, the current better regulation agenda of the EU is still full of evidence-based thinking (CEC, 2015). This type of policy-making assumes that when you increase the quality and quantity of knowledge and information used in the formulation of policy, policy-making becomes more 
technical, and thus more amendable to rational decision-making (in other words, less wicked). The goal of evidence-based policy is to use verifiable research results to inform policy-making; it attempts to make policy problems appear more technical and less social or political. As such, it often goes together with an attempt by governments to introduce business-type risk management practices (often via specialist regulatory agencies) (Hutter, 2005). An appeal to evidence-based policy-making, is an appeal to technocratic policy-making; evidence-based policy-making indicates a strong reliance on experts and expertise in the policy process. But what we have just learned from the different conceptualizations of complex policy problems is the understanding that we lack knowledge about both the specific problem at hand as well as about the potential solutions to solve them. In order to regulate in a situation with such a knowledge deficit, the obvious reaction of political actors involved in the game is to increase our knowledge, and thus involve experts and scientific advice. What are the implications of a policy process that almost automatically turns to science and expertise in the face of uncertainty?

Critics of evidence-based policy argue that evidence is rarely objective and in principle value-laden. If we follow Schön (1983) in his understanding of policy-making as a messy swamp, the only thing evidence-based policy-making can do is to map the mess. Evidence-based policy-making is then considered a step backwards rather than forwards, in that it is a 'return to the quest for a positivist yellow brick road leading to a promised policy dry ground' (Parsons, 2002: 45). What's more, evidence-based policymaking has the danger of 'experts' resorting to 'ghost-writing', producing evidence in favor of a preferred policy solution, or 'silencing' evidence arguing against the preferred policy solution (Mansnerus, 2010). In other words, experts tend to give the 'scientific' advice that they know to be politically acceptable (Levidow et al., 2005). Hilgartner (2000) argues that expertise is never purely objective because it is shaped and formed by contextual factors. When expertise would be transparent, it would make this subjectivity visible. Thus experts often 'hide', or 'backstage' certain information. In sum, we should be careful not to automatically rely on expert advice as the solution to the problem of regulating complexity. 


\section{The European regulatory state at risk? Challenges of the regulation of complex policy problems in the EU}

Let's now finally come to the most interesting part of this lecture. What do we make of all of this? What can we learn from these different disciplinary perspectives on complex policy problems and the way the EU is currently responding to this? What are the core challenges of the regulation of complex policy problems in the EU?

Taking the impact of limited human capacity, bounded rationality, and perceptions seriously

We thus know that how we think about complex policy problems is socially constructed and varies in different societal contexts. Perceptions and responses to complexity can only be understood against the background of people's embeddedness in a sociocultural background (Taylor-Gooby and Zinn, 2006: 37). Douglas and Wildavsky (1984) have argued that social and cultural processes determine which risks societies fear and which they ignore. How people perceive complex policy problems is thus influenced by the relevant context, and this in turn influences behavior. This is linked to the notion of bounded rationality (Simon, 1982). There is only so much capacity to process information and estimate probabilities. Thus '[e]motions and worldviews ... both may help us navigate quickly and efficiently through a complex, uncertain, and sometimes dangerous world' (Slovic, 1999: 694). The impact of bounded rationality can be further illustrated by how people look at risks. We know from cognitive social psychology that initial perceptions about risks structure the way new evidence about these risks is interpreted: new evidence will particularly be perceived as reliable when it is in line with one's own initial belief (Slovic et al, 1984: 184). We also know that men tend to judge risks as smaller than women, white male consider risks as lower than non-white male, and better educated, high income and politically conservative white male belong to the group with the lowest risk perception (Slovic, 1999). Let's illustrate this with the example of the refugee crisis. Where you live, your cultural and religious background, what political affiliation you have, your own economic situation - this all influences how you initially think about refugees, and this in turn obviously influences how you think about the current refugee crisis. If you have an initial belief that refugees are welcome, you will be likely to defend refugees when confronted with new evidence such as the recent situation in Cologne. Someone with an initial negative belief will respond differently, and perceive this news differently.

Just as much as individuals are bounded in their rationality, so are governments and other organizations. Just as individuals, organizations face considerable information processing and decision-making challenges, and they generally 'display a tendency towards risk aversion and negativity bias' (Lodge and Wegrich, 2014: 6). This also influences that organizations tend to confirm rather than challenge existing ways of doing things (March, 1991). There is a natural tendency to 'decomplexification' along the lines of the known. In sum, bounded rationality in organizations stands in the way of 
creativity and causes a 'confirmation bias that puts a premium on default strategies' (Lodge and Wegrich, 2014: 8). This is problematic in the regulation of complex policy issues. As Baldwin (2010) argued, in order to address complexity, we need to encourage 'clumsy' solutions.

What type of characteristics does the EU need to have in order to regulate complexity? On participation, leadership, and flexibility

To recap, complex policy problems cannot be objectively defined, nor definitely solved. And in order to be able to address them, we have to be able to accept and work with the notion that science and expertise is never complete nor objective, and that people deciding about complex policy issues will be influenced by their own limited capacity and perceptions. Is all hope lost then, or can we define specific characteristics that might work in tackling complex policy problems? Let's discuss participation, leadership, and flexibility.

Broadly speaking, the literature identifies various ideal-types of responses to complex policy problems: a more authoritative versus a more participatory approach. The authoritative approach relies on a strong leader with directive authority. The idealtypical participatory approach rests on public consultation and participation. The jury is still out as to what political organizations that need to deal with complex policy problems need to resort to: do they need to show strong leadership via top-down decision-making, or do they need to open up the policy process and call for deliberation and wide participation?

The most widespread response by governments is some form of collaborative or networked management (Head and Alford, 2015). This is also reflected in the EU. Already since the Laeken Declaration of 2001, the call for more participation is widespread within the EU, and we currently still witness this within the recent better regulation agenda (e.g. CEC, 2015). Widening participation is thought to improve the quality of regulation, better serve the public interest and improve public awareness (Rothstein, 2003). We can identify three types of rationale for broadening participation in order to deal with complex policy problems (based on Rothstein, 2003). A normative rationale that holds that deciding about complex problems is never value-free, and thus broader participation - listening to a wider range of social and ethical judgments - is required in order to provide for more democratic legitimacy. A second rationale is epistemic and holds that policy-makers need to draw on alternative sources of information outside the traditional regulatory structures, simply because there is no full information in complex policy decision-processes. The instrumental rationale, finally, holds that wider participation is necessary to ensure political viability in the age of declining trust in political institutions. Based on the analysis of participative risk regulation in the case of BSE in sheep in the UK, Rothstein (2003) concludes that we need to be careful in expecting too much of opening up the policy process. Participation as such is an insufficient criterion. Its success depends on who participates, who they 
represent, power balances between the participants, as well as the ability of the participants to handle complex and uncertain information. One thing is clear, Rothstein argues, there is no proof for the epistemic rationale for participation: 'openness per se does not necessarily produce more robust policy outcomes than closed processes' (Rothstein, 2003: 17). Turnpenny et al. (2009) share this criticism about the positive effect of participation. Particularly in the context of the EU, deliberative problem-solving appears only effective when politicization is low (when there are no clear national preferences), and this is very unlikely in the case of complex policy problems.

It is also argued, however, that more cooperation between stakeholders is likely to lead to a common understanding of the problem at hand, and thus it is more likely that solutions are accepted and agreed upon. One can see this as a process of socialization or internalization as described by constructivists. In addition, the more collaboration, and thus potential agreement on the road ahead, the more likely the chances of compliance. More collaboration 'increases the probability that parties will feel comfortable about revealing information that may make them vulnerable to opportunistic behavior by other parties' (Head and Alford, 2015: 727). An environment of trust is important here. It thus seems that what deliberation and participation can bring, is not so much a better policy outcome, but rather potentially acceptance about the solution chosen. As Conklin states: 'You don't so much 'solve' a wicked problem as you help stakeholders negotiate shared understanding and shared meaning about a problem and its possible solutions' (2007: 5, quoted in Head and Alford, 2015: 718). As governments need to make 'tragic choices' (Calabrese and Bobbitt, 1978, quoted in Peters, 2015: 27) - that is, solutions for complex policy problems will always simultaneously have advantages in some areas and disadvantages in other areas - they better ensure they are on a good footing with all participants in the game in order to ensure acceptance.

Every scholar writing about the vices and virtues of participation, also discusses leadership. There is a fine line between where political leaders need to position themselves: as authoritative leaders or participatory team-players. As Head and Alford (2015) stress, collaboration needs to go hand in hand with broader ways of thinking (cf. flexibility, adaptive capacity) and new models of leadership. Addressing complex policy problems requires a mode of leadership that is capable of creating some degree of shared understanding, agreed purposes, mutual trust and an element of interdependence (Head and Alford, 2015). The traditional understanding is that a good leader needs to be able to frame a vision for the organization, and to get others to pursue that vision by inspiring them to do so. This, however, becomes problematic in the case of complex policy problems. In such cases, the leader should less focus on a vision - how can he or she in instances where the problem is not known, nor are the solutions - but should rather engage in the 'mobilization of adaptive work'. Such leaders should 'go beyond the traditional notion of top-down direction ... and lead ... stakeholders in undertaking themselves the collective work of grappling with the problem' (Head and Alford, 2015: 729, based on Heifetz, 1994). This, in sum, requires more a form of shared leadership. Heifetz (1994; quoted in Head and Alford, 2015) stresses the need for 
adaptive leadership where the role of the leader is to challenge and assist stakeholders to understand the difficult choices they have to make and to deliberate about ways forward.

Next to the leadership-participation nexus, let's discuss the need for flexibility, or adaptive capacity, and thus for learning. As change is here to stay (Schön, 1983), the critical question we need to ask ourselves is how we can develop a system that can capture change and complexity. Dealing with complex policy problems requires flexibility and new ways of thinking and the necessity to be able to switch in both problem definition and solution (e.g. Head and Alford, 2015). Phrased differently, organizations need 'adaptive capacity' in order to be able to cope with complexity (Duit and Galaz, 2008: 318). Following March (1991), the adaptive capacity of organizations rests on how they deal with the tension between 'exploration' and 'exploitation'. Here exploration relates to terms such as 'search, variation, risk taking, experimentation, play, flexibility, discovery, innovation'. Exploitation resorts to 'refinement, choice, production, efficiency, selection, implementation, execution' (March, 1991: 71). This trade-off is rooted in a more fundamental tension between the need for institutional stability and change, and particularly exploration is required when managing complex policy issues (cf. Duit and Galaz, 2008: 320). When looking at the European Union, it seems to rest more on those key words associated with exploitation, more than those describing exploration. In order to be able to become a better manager of complex policy problems, it requires the EU to work on its flexibility and learning capacity. In order to control the messy swamp, in Schön's terminology, governments need to act as a 'facilitator of society's learning' (Parsons, 2002: 48). Governments should not act as problem solvers remember, the problems cannot be adequately solved - but facilitate private and public learning.

We learn from all of this that in order to deal with complexity, a political organization

a) needs to rely on stakeholder participation - not so much because this will lead to answers to questions, or better policy outcomes, but because it is likely to create trust and acceptance;

b) needs to demonstrate leadership - not the top-down, authoritative type, but a shared / adaptive leadership style that focuses on triggering learning;

c) and needs to have adaptive capacity to be able to respond to complex policy problems - this adaptive capacity requires risk taking, experimentation and flexibility. 


\section{Then what? What should the EU do, or not do when confronted with complex policy problems?}

I do not claim that I have the definitive answer to the question what the EU should do to regulate complex policy problems. The careful listener realizes that this is not possible. There is no such a thing as a golden mix, or a golden approach, as every complex policy problem is unique.

It is crucial that the actors involved in the regulation of complex policy problems acknowledge that there is no consensus on the problem at stake, nor on the solutions required; acknowledge the limits of knowledge and expertise; and acknowledge the persistence of uncertainty. Complex policy problems are decision problems, requiring judgment and valuation, requiring a choice among alternatives, although there are no right or wrong solutions (Slovic et al., 1984; Adams, 2004). As such, regulating complex policy problems per definition touches upon a moral dimension (Wexler, 2009). By ignoring all of this, regulators run the risk of false assurance (Wexler, 2009).

Many of the problems related to regulating complexity are blown up at the EU level. In order to regulate complex policy issues in the EU, we need to a) accept the limits to expertise and scientific certainty, b) accept the existence of 28 different contextual situations (i.e. never a consensus on the problem as such, nor on the potential solutions), c) accept that not all member states will always comply with all solutions found.

Regulation is still too often assuming the above: relying on expertise to provide the answer, assuming that one size fits all, and relying too much on a situation of full compliance. Any regulatory answer to complex policy problems should reflect these three issues. What does this imply? More flexibility in the regulatory solutions found; let go of the idea that the same solutions work in all cases. Head and Alford (2015: 718) already argued 'for a more pragmatic approach, in which the type of response is tailored to the types of wickedness the problem seems to exhibit'. I would like to take this one step further. Rather than only focusing on the 'type of wickedness', or type of complexity, it is crucial to also consider the perceptional variation in the EU-28. It is too often the case that particular forms of intervention tend to be routinely applied in a 'onesize-fits-all' fashion to a variety of situations (also see Alford and Hughes, 2008; Turnpenny et al, 2009). Strategies might work under certain circumstances, but not in others. Complex problems are never the same; there are no general laws for complexity (Goldenfeld and Kadanoff, 1999). And thus each new problem requires a particular handling. And this in turn requires a regulatory system that acknowledges the uncertainties, that is flexible in addressing these uncertainties. In an EU that is prone to harmonization, this perhaps requires a turn to allowing more flexibility. As Bentley (2002: 17) stated: 'The challenge is to recreate public institutions and governance regimes as open, porous and decentred systems which can thrive on diversity, adapt to radical innovation and still maintain coherent purpose and progress'. 
Let's return to the example of a current complex policy problem the EU is struggling with: the refugee crisis. We indeed witness everything identified in this lecture. There is no agreement on the problem at hand. Different actors define and categorize the problem differently. In turn, this influences that there is no consensus on the potential solutions. Those framing the refugee crisis as a terrorism problem are bound to identify different solutions compared to those framing it along the lines of economic migration. There is no complete knowledge about the state of affair: no expert can claim with certainty if or when the crisis in Syria will be solved, how this will impact migration streams, and what type of people will flee to Europe, and what impact this will have on domestic situations in various parts of the EU. What we currently often witness, and the refugee crisis is no exception to this rule, is inertia. The EU is often not able to respond to complex policy problems.

What I have tried to show today, is that we need to let go of the idea that complex policy problems can be solved uniformly in all 28 Member States of the EU. As Parsons (2002) stated before me, we need to accept diversity, embrace the possibility of failure, and recognize the importance of context. My claim is thus that we need to allow for more flexibility, more enhanced cooperation, and more self-organization in the EU. This goes directly against the words of the Dutch prime minister Rutte, who stated a couple of weeks ago with the start of the Dutch Presidency, that a 'discussion on "a Europe of many speeds or one speed of whatever" is less important than getting to grips with border security and refugee burden sharing' (EUObserver, 7 January 2016). I claim that this discussion is important. We need to think about what can be regulated at the EU level, not only in terms of subsidiarity, but also in terms of feasibility. I thus claim that the EU should be less afraid to allow differential, more tailored, approaches that more directly speak to the variation in an international organization with 28 members. This is difficult. It will most likely not be politically acceptable for the Member States, to not always know beforehand what action will be taken in what specific situation. And it will perhaps also not be realistic, as we learn from bounded rationality that people have great difficulties in working with uncertainty. But, the EU can only speak to complex problems by turning to more complex solutions. And this is obviously a difficult message to sell to the public in times of increasing populism. 


\section{References}

Adams, D. (2004) 'Usable knowledge in public policy', Australian Journal of Public Administration, 63(1): 29-42.

Alford, J. and O. Hughes (2008) 'Public value pragmatism as the next phase of public management', The American Review of Public Administration, 38(2): 130-148.

Alink, F., A. Boin and P. 't Hart (2001) 'Institutional crises and reform in policy sectors: the case of asylum policy in Europe', Journal of European Public Policy, 8(2): 286-306.

Asselt, M. van and E. Vos (2008) 'Wrestling with uncertain risks: EU regulation of GMOs and the uncertainty paradox', Journal of Risk Research, 11: 281-300.

Baldwin, R. (2010) 'Better regulation: the search and the struggle', In: Baldwin, R., Cave, M, and Lodge, M. (eds.) The Oxford Handbook on Regulation. Oxford University Press, Oxford, 259-278.

Beck, U. (1986). Die Risikogesellschaft. Auf dem Weg in eine andere Moderne, Frankfurt, Main: Suhrkamp.

Bentley, T. (2002) 'Letting go: complexity, individualism and the left', Renewal, 10(1): 926.

Birkland, T.A. (2006) Lessons of Disaster. Policy change after catastrophic events, Washington D.C.: Georgetown University Press.

Boin, A. (2004) 'Lessons from crises research', International Studies Review, 6: 165-174.

Boin, A., P. 't Hart and A. McConnell (2009) 'Crisis exploitation: political and policy impacts of framing contests', Journal or European Public Policy, 16(1): 81-106.

Borrás, S. and C.M. Radaelli (2011) 'The politics of governance architectures: creation, change and effects of the EU Lisbon Strategy', Journal of European Public Policy, 18(4): 463-484.

Braun, D. and F. Gilardi (eds.) (2006) Delegation in Contemporary Democracies, New York: Routledge.

Commission of the European Communities (CEC) (2015) Better Regulation for better results - An EU agenda, COM(2015)215, Strasbourg.

Coyne, R. (2005) 'Wicked problems revisited’, Design Studies, 26(1): 5-17.

Douglas, M. and A. Wildavsky (1982) Risk and Culture: An Essay on the Selection of Technical and Environmental Dangers, Berkeley: University of California Press. 
Duit, A. and V. Galaz (2008) 'Governance and complexity - Emerging issues for governance theory', Governance: An International Journal of Policy, Administration and Institutions, 21(3): 311-335.

Durant, R.F. and J.S. Legge (2006) “'Wicked problems", public policy and administrative theory', Administration \& Society, 38(3): 309-334.

Gilardi, F. (2002) 'Policy credibility and delegation to independent regulatory agencies: a comparative empirical analysis', Journal of European Public Policy, 9(6): 873-893.

Goldenfeld, N. and L.P. Kadanoff (1999) 'Simple lessons from complexity', Science, 284(5411): 87-89.

Head, B.W. and J. Alford (2015) 'Wicked problems: implications for public policy and management', Administration and Society, 47(6): 711-739.

Hilgartner, S. (2000) Science on Stage. Expert Advice as Public Drama, Stanford University Press.

Hoenderkamp, J. (1998) De sociale pijler. Ambities en praktijken van het grotestedenbeleid, Den Haag: Sociaal Cultureel Planbureau.

Hutter, B.M. (2005) 'The attractions of risk-based regulation: Accounting for the emergence of risk ideas in regulation', CARR Discussion Paper No. 33, Centre for Analysis of Risk and Regulation, London.

Jasanoff, S., and Wynne, B. (1998) 'Science and decision making', in: Rayner, S. and Malone, E.L. (Eds.) Human choice and climate change, Columbus, OH: Battelle, 1-87.

Levidow, L., S. Carr and D. Wield (2005) 'European Union regulation of agribiotechnology: precautionary links between science, expertise and policy', Science and Public Policy, 32(4): 261-276.

Levi-Faur, D. (2010) 'Regulation \& Regulatory Governance', Jerusalem Papers in Regulation \& Governance, Working Paper No. 1, February 2010.

Lodge, M. and K. Wegrich (2014) 'Rational tools of government in a world of bounded rationality', CARR Discussion Paper No. 75, Centre for Analysis of Risk and Regulation, London.

Lyotard, J.F. (1986) The postmodern condition: a report on knowledge, Manchester: Manchester University Press.

Majone, G. (1997) 'From the positive to the regulatory state: Causes and consequences of changes in the mode of governance', Journal of Public Policy, 17(2): 139-167. 
Mansnerus, E. (2010) 'Silence of evidence in the case of pandemic influenza risk assessment', CARR Discussion Paper No. 60, Centre for Analysis of Risk and Regulation, London.

March, J.G. (1991) 'Exploration and exploitation in organizational learning', Organization Science, 2(1): 71-87.

Mitroff, I.I., M.C. Alpaslan and S.E. Green (2004) 'Crises as ill-structured messes', International Studies Review, 6: 175-182.

Parsons, W. (2002) 'From muddling through to muddling up - Evidence based policy making and the modernization of British government', Public Policy and Administration, 17(3): 43-60.

Peters, B.G. (2015) Advanced Introduction to Public Policy, Cheltenham, UK: Edward Elgar.

Radaelli, C.M. (1999) 'The public policy of the European Union: whither politics of expertise?', Journal of European Public Policy, 6(5): 757-74.

Rittel, H.J.W. and M. Webber (1973) 'Dilemmas in a general theory of planning', Policy Sciences, 4(2): 155-169.

Rothstein, H. (2003) 'Precautionary bans or sacrificial lambs? Participative risk regulation and the reform of the UK food safety regime', CARR Discussion Paper No. 15, Centre for Analysis of Risk and Regulation, London.

Schillemans, T. (2013) 'Het eindeloze verhaal van de bestuurskunde: complexiteit, vernieuwing en de Big Society', Bestuurskunde, 22(1): 70-80.

Schön, D.A. (1983) The Reflective Practitioner, New York: Basic Books.

Scott, C. (2001) 'Analyzing Regulatory Space: Fragmented resources and institutional design', Public Law, 283-305.

Simon, H.A. (1982) Models of Bounded Rationality. 2 vols, Cambridge, MA: MIT Press.

Slovic, P. (1999) 'Trust, Emotion, Sex Politics and Science - Surveying the Risk Assessment Battlefield', Risk Analysis, 19(4): 689-701.

Slovic, P., B. Fischhoff and S. Lichtenstein (1984) 'Behavioural Decision theory on risk and safety', Acta Psychologica, 56: 183-203.

Taylor-Gooby, P. and J. Zinn (eds.) (2006) Risk in Social Science, Oxford: Oxford University Press.

Turnpenny, J., I. Lorenzoni and M. Jones (2009) 'Noisy and definitely not normal: responding to wicked issues in the environment, energy and health', Environmental Science \& Policy, 12(3): 347-358. 
Wexler, M.N. (2009) 'Exploring the moral dimension of wicked problems', International Journal of Sociology and Social Policy, 29(9/10): 531-542.

Wildavsky, A. (1988) Searching for Safety, New Brunswick: Transaction Books.

Wildavsky, A. and K. Drake (1990) 'Theories of Risk Perception: Who fears what and why?', Daedalus, 119(4): 41-60. 